for RGA. Apparent NRNA digestibility in the intestine (73, 85 and $83 \%$ for HPC, RGA, and M) was higher than total $\mathrm{N}$ digestibility $(50$ to $81 \%$ ) : this pointed out the very high degradability of RNA in the intestine. The mean flow of digested NRNA represented $9 \%$ of the amount of total digested nitrogen.

A total of 25 to 50 and $86 \%$ of total digested nitrogen (for diets M, HPC, RGA respectively) was excreted in urine. Urinary nitrogen allantoïn represented between $35 \%$ (HPC) and $58 \%$ for RGA $(47 \%$ for $M)$ of the amount of digested NRNA and 4 to $12 \%$ of total urinary nitrogen. Purine nitrogen valorization could then be estimated between 42 to $65 \%$. This value seemed to be higher for lactating goats than for sheep or billy goats at maintenance.

All these results show that the dairy goat can utilize as well NRNA as total nitrogen coming out at the duodenal level.

Key words: Nitrogen flow, nitrogen metabolism, goat.

\title{
Feed intake, digestibility and nitrogen retention in lactating dairy goats fed increments of urea and fish meal
}

\author{
J.E. LINDBERG, P. CISZUK \\ Swedish University of Agricultural Sciences, Department of Animal Nutrition and Management, \\ Kungsängens gård, S-755 90 Uppsala (Sweden)
}

Balance measurements were made in dairy goats of the Swedish Landrace breed. A total of 14 goats with an average live weight of $49 \mathrm{~kg}$ were used during the 3 experimental years.

Experimental diets were composed of $400 \mathrm{~g} \cdot \mathrm{kg}^{-1}$ hay and $600 \mathrm{~g} \cdot \mathrm{kg}^{-1}$ concentrate mixture on feed basis. The concentrate mixtures were not supplemented or supplemented with increasing amounts of urea $(0.9,1.8,2.7$ and $3.5 \%)$ and fish meal $(3.9,7.9,11.7$ and $15.8 \%)$.

A standard diet $\left(344 \mathrm{~g} \cdot \mathrm{kg}^{-1}\right.$ hay and $656 \mathrm{~g} \cdot \mathrm{kg}^{-1}$ concentrate mixture $)$ was fed after parturition and between experimental periods as a reference diet to establish the production capacity of each goat. The standard concentrate was composed of barley, oats, molasses-beet pulp, wheat bran and soyabean meal.

All diets were fed ad libitum. Collections were made for two weeks after an adaptation period of at least three weeks to experimental diets and two weeks to the standard diet. Buffer-soluble crude protein was analysed with a mineral buffer adjusted to $\mathrm{pH}$ 6.7-6.9 and rumen degradability of crude protein was determined with nylon bags with $20 \mu \mathrm{m}$ pore size.

There was a gradual increase in buffer-soluble crude protein (BSCP) and rumen degradable crude protein (EPD) in concentrates with added urea. The opposite was true in concentrates with added fish meal. EPD and BSCP in concentrate mixtures were linearly $(P<0.001)$ related $\left(r^{2}=0.72\right)$.

The average feed intake was $86.4 \mathrm{~g} / \mathrm{kg} \mathrm{P} 0.75(\mathrm{SD}=4.7)$. Feed intake showed large between animal variation, mostly marked at low and at high crude protein content in the diet. The relative feed intake (in $\%$ of intake on the standard diet) decreased significantly $(P<0.01)$ with increasing urea and fish meal supplementation. However, milk protein production was well maintained on the fish meal diets.

Organic matter digestibility was similar on all diets $(73 \%, \mathrm{SD}=0.7)$. Crude fibre (CF) digestibility varied between diets, but was significantly $(P<0.001)$ related to the amount of BSCP in feed organic matter in unsupplemented and fish meal supplemented diets. Significant $(P<0.05)$ individual differences in CF digestibility were also noticed.

The nitrogen balances (total $\mathrm{N}$ retention - milk $\mathrm{N}$ ) were not significantly influenced by the diets fed and was on average $1.9 \mathrm{~g} \mathrm{~N}$ per day $(\mathrm{SD}=0.6)$. The milk $\mathrm{N}$ output was on average $12.4 \mathrm{~g} / \mathrm{d}(\mathrm{SD}=1.5)$ on the experimental diets. Increasing supplementation of urea, above the 
basal hay and grain diet with $90 \mathrm{~g}$ rumen degradable crude protein in the DM, was not significantly related to any increase in nitrogen accretion. Fish meal addition, on the other hand, gave a significant curve-linear increase in nitrogen retention in milk. Optimal level of fish meal inclusion was depended on fish meal quality, but was in the range 10 to $12 \%$ in the concentrate.

Key words: Feed intake, nitrogen retention, goat, urea, fish meal.

\title{
Effect of addition of animal or vegetable fat to a hay based diet on digestibility and nitrogen balance in the lactating goat
}

\section{R. DACCORD}

\author{
Swiss Federal Research Station for Animal Production, Grangeneuve, CH-1725 Posieux
}

At the beginning of lactation, the high producing ruminant is subjected to the energy deficiency. In production systems where forage intake is predominant like in Switzerland, energy deficiency can be coupled with a low intake of fatty acids, particularly when hay rations are complemented with fodder beets. Supplementation of such diets with animal or vegetable fat was studied in a balance experiment performed in goats.

A total of 15 lactating goats were assigned to three diets based on hay, fodder beets and on the following concentrates: $\mathrm{A}=$ cereals and soybean meal $(16 \%), \mathrm{B}=$ as $\mathrm{A}$, but with an addition of $4 \%$ micronized animal fat, $\mathrm{C}=$ as $\mathrm{A}$, but replacing soybean meal by extruded soybean $(20 \%)$. Concentrates were iso-nitrogenous, containing $2.0,5.9,6.0 \%$ crude fat in the DM respectively. All diets were given ad libitum. On a net energy basis, they were made up of $50 \%$ hay, $25 \%$ fodder beets and $25 \%$ concentrates.

Goats fed diet $\mathrm{A}$ had the highest intake $(\mathrm{kg} / \mathrm{day}: \mathrm{A}=2.152 ; \mathrm{B}=2.061 ; \mathrm{C}=2.027$; $s_{\bar{x}}=0.114$ ). Digestibility of all the main nutrients except crude fat was lower with diet $B$. Digestibility of organic matter, crude protein and crude fat was higher with diet $\mathrm{C}$. The fibre fraction had the highest digestibility with diet $\mathrm{A}\left(\mathrm{A}=62.0 ; \mathrm{B}=59.1 ; \mathrm{C}=60.7 ; \mathrm{s}_{\bar{x}}=1.2\right)$. Diet $\mathrm{C}$ decreased the proportion of faecal $\mathrm{N}$ and increased the proportion of urine $\mathrm{N}$ ( $\mathrm{N}$-urine, \% $\mathrm{N}$ intake: $\left.\mathrm{A}=25.8^{\mathrm{ab}} ; \mathrm{B}=22.2^{\mathrm{a}} ; \mathrm{C}=29.7^{\mathrm{b}} ; \mathrm{P}<0.05\right)$. Diet $\mathrm{B}$ had the best efficiency of $\mathrm{N}$ utilization. The main mineral balances were not affected by the diet.

Production of $3 \%$ fat corrected milk was lowest with diet $\mathrm{C}(\mathrm{kg} / \mathrm{day}: \mathrm{A}=3.58 ; \mathrm{B}=3.73$; $\mathrm{C}=3.15, \mathrm{~s}_{\overline{\mathrm{x}}}=0.22$ ). Both diets with higher fat content increased the protein and fat content of milk (protein $\%: \mathrm{A}=2.67^{\mathrm{a}} ; \mathrm{B}=2.81^{\mathrm{b}} ; \mathrm{C}=2.86^{\mathrm{b}} ; \mathrm{P}<0.05 ;$ fat $\%: \mathrm{A}=2.83 ; \mathrm{B}=3.20$; $\mathrm{C}=3.28$ ). These diets decreased the content of middle chain fatty acids and increased that of long chain fatty acids.

The dietary treatments had no significant effect on the concentration of blood metabolites and enzymes, except for cholesterol, whose level was increased with fat supplements.

In conclusion, addition of a limited amount of a good quality fat (of animal or vegetable origin) to a forage-based diet can be a valuable solution for increasing concentrated energy and fatty acids in the diet of high producing ruminants.

Key words: Fat, nitrogen balance, digestibility, goat.

\section{Effect of a high dietary potassium content on Mg-, K- and Na-metabolism in the lactating goat}

\section{J. KESSLER}

Swiss Federal Research Station for Animal Production, Grangeneuve, CH-1725 Posieux

Only fragmentary information on K-requirement of goats is available. As in sheep the net minimum endogenous requirement can be fixed at $20 \mathrm{mg} \mathrm{K} / \mathrm{kg}$ live weight. The net requirement 